\title{
Seeking Employment in the British Empire: Three Letters from Rajah Gobind Ram Bahadur
}

\section{by Alan M. Guenther}

\begin{abstract}
Three short $18^{\text {th }}$ century Persian language letters in the manuscript collection of the Division of Rare Books and Special Collections, McLennan Library, along with the story of how they came to McGill University, provide a fascinating window on the British Empire and the efforts of imperial subjects to obtain employment. The story begins in Bengal where a rising civil servant, Raja Gobind Ram, at a difficult time in bis life, petitions his friend David Anderson for assistance. Gobind Ram achieves success, holding eventually posts of considerable responsibility in nascent British India. When, in the late $19^{\text {th }}$ century, the letters come to Canada, the story introduces a young Scottish entrepreneur and immigrant, J. K. Oswald, and his pursuit of employment - first in the financial world of Montreal and later in public service at the then small settlement of Calgary - during the years when the Canadian Pacific Railway was opening up Western Canada, and Louis Riel was leading the Northwest Rebellion of 1885.
\end{abstract}

\section{RESUMÉ}

Un coup d'eil fascinant sur l'empire britannique et sur les efforts déployés par ses sujets pour trouver du travail est offert par trois courtes lettres en langue perse datant du 18 e siècle et par l'bistoire du cheminement par lequel elles sont parvenues à l'Université McGill, où elles résident présentement à la Division des livres rares et des collections spéciales de la Bibliothèque McLennan. L'bistoire débute au Bengale, avec la demande d'aide adressée par le fonctionnaire Raja Gobind Ram lors d'un moment difficile de sa vie à son ami David Anderson. Gobind Ram accéda éventuellement à des postes d'importance considérable en Inde à l'aube de l'époque d'administration britannique. Ces lettres sont parvenue au Canada vers la fin du 19e siècle, et c'est à cette étape du récit que nous rencontrons James Kidd Oswald, un jeune entrepreneur et immigrant écossais. Nous le suivons alors qu'il cherche du travail - d'abord dans le monde financier de Montréal, puis à titre de fonctionnaire dans ce qui était alors la petite ville de Calgary - au cours des années qui ont vu la compagnie de chemins de fer Canadian Pacific ouvrir les portes de l'ouest canadien et Louis Riel mener la rébellion de 1885.

he British Empire as an international
commercial enterprise run by Scotsmen
is a contention well exemplified in stories, crossing three continents and two centuries, accompanying three manuscript letters in the McLennan Library's Division of Rare Books and Special Collections. These letters, designated "A," "B" and "C," of Manuscript 971, were written in Persian by an Indian official to a Scottish employee of the East India Company in Bengal in the 1770s, and found their way to McGill University over one hundred years later. Although the content of the letters is interesting, even more interesting are the events and lives intertwined with them in Scotland, British India, and post-Confederation Canada. The reach of Scottish mercantile families throughout British Empire during the $18^{\text {th }}, 19^{\text {th }}$, and $20^{\text {th }}$ centuries emerges with clarity. This paper is divided into three sections: first, the people and circumstances 
surrounding the original correspondence in $18^{\text {th }}$ century India; second, the people and circumstances surrounding the correspondence finding a home at McGill in the 1890s; and third, description and translation of the three letters. Seeking employment emerges as the preoccupation of everyone connected with the letters.

\section{CONTENT OF THE LETTERS}

The letters from Rajah Gobind Ram Bahadur to David Anderson were written at a critical point in the demise of the Mughal rule and the consolidation of the British power in the Bengal region of India in the latter half of the $18^{\text {th }}$ century. In 1756 , the Nawab of Bengal, Siraj-ud-daula saw British expansion of the fortifications of Calcutta as a challenge to his rule and marched on the city, capturing the garrison. ${ }^{1}$ The British retaliated and retook Calcutta under Colonel Robert Clive early the following year, and then moved to extend their control in the region by defeating the Nawab's forces at the battle of Plassey on 23 June 1757. After another decisive battle at Buxar in 1764, when the British forces were victorious over the allied forces of the Nawabs of Bengal and Awadh as well as those of the Mughal emperor, the British East India Company secured the diwāni, or revenue collecting rights, in the region through a treaty with the Mughal emperor. In a move to bring order from chaos in the shifting authority of the region, the directors of the Company appointed Warren Hastings as the first Governor-General of its Indian territories in 1772. From the content of the letters, it is evident that they were written in the period 1772 to 1775 , during the early years of the Hastings administration.

\section{Rajah Gobind Ram Bahadur (d. 1788)}

Included with the three letters is an envelope identifying both the writer and the recipient, as well as clues to dating the letters. The letters' author, as engraved on the seal on the envelope, is Raja Gobind Ram Bahadur, whose full title is given in the Imperial Record Department in New Delhi as Prithvi Indar Amīr-ul-Mulk Imtiāz-ud-Daulah Farzand-i-Wafādar Rāja Mirza Gōbind Rām Bahādur Sipāhdar Jang. ${ }^{2}$ Within a few years of writing these letters, he came to prominence as the vakil or ambassador of the Nawab Asaf-ud-Daulah of Awadh, acting as the Nawab's representative to the East India Company at Calcutta from 1775 to $1788^{3}$ His younger brother was Rao Anant Ram. ${ }^{4}$ Gobind Ram, according to his own testimony, had become acquainted with David Anderson some time prior to writing the first letter, and had been the recipient of his financial aid. The occasion of the correspondence was Ram's straitened circumstances and desperate need of employment.

Gobind Ram describes himself in the first letter as having fallen "victim to many a disease beyond description and for three or four years was confined to bed." This would coincide with the devastating famine, accompanied by cholera, small pox and other diseases, which afflicted Murshidabad and other parts of Bengal in $1770 .{ }^{5}$ Treatment for the diseases consumed his resources, including the gift he had received from Anderson. Although Ram notes that his health has begun to mend, he feels that he is not yet strong enough to offer his services to Anderson wherever he might be serving at the time. Instead, Ram was remaining in Calcutta, where no one had come to his aid. In the letter, Gobind Ram laments that he is currently without a significant post, and requests recommendations from Anderson that would open doors to influential officials who could provide such an important post. The "wrong movement of the spheres" of which he was complaining very quickly gave way to the ascension of Gobind Ram's star, as his subsequent career would show. 


\section{David Anderson (1750-1825)}

The envelope containing the letters is addressed to"Fakhar-ud-Dawlah Dāud Anderson Sāhib Bahādur" the honorific title for David Anderson, an East India Company official. Because he was rising in rank and responsibility in the Company, and closely allied with Governor-General Warren Hastings, Anderson was a logical choice to be approached by a friend such as Gobind Ram seeking government employment. Unlike Gobind Ram, of whose activities prior to 1775 almost no record can be found, David Anderson is mentioned regularly in the records of East India Company. He arrived in India on 11 July 1767 in the position of Writer - copy clerk - and in the following year was appointed Assistant under the Secretary of the Select Committee. In 1769 he served as an assistant to George Gustavas Ducarel in Purnea district. ${ }^{6}$ One year later, he became an Assistant at the Durbar. In 1772 he moved to Murshidabad where he was appointed Factor, Assistant to the Resident. He held the position of Fifth in Council at Murshidabad in 1774, Junior Merchant and Fourth in Council at Murshidabad two years later, and continued advancing in rank during the years that followed. ${ }^{7}$

In the first letter, Gobind Ram laments that Anderson had departed from the town leaving him destitute of friends as well as resources, which suggests that it was written shortly after Anderson's departure in 1772 to become assistant to Samuel Middleton, the Resident at Murshidabad. In a letter home to his parents, Anderson indicated that he acted as Resident in Middleton's absence: "Mr. Middleton's absence has thrown upon me the Charge of two of the most important offices under the Government, the Residency at the Durbar and the Collectorship of Rajeshahy." ${ }^{8} \mathrm{He}$ also outlined the judicial responsibilities his assignment entailed:

My present appointment is Persian Translator to the Durbar, in which capacity Mr. Midd. has entrusted to me the Superintendence (under him) of the administration of Justice. This office does not require so great a share or Capacity of Knowledge as you would imagine. The Decrees are guided by the Mussulman and Gentoo Laws, and I have always 3 or 4 learned men to expound them, and it is only when no Law can be found, that I allow my own notions of Equity to regulate my Determinations. An Appeal may be made to the President and Council to that the parties may always be sure of Redress. This Employment gives me a great Deal of Trouble, but it gives me a Considerable Influence in this part of the Country. I still enjoy the advantages of my paymastership, and I have lately made an addition to my Income by establishing a manufactory for Gold thread in the City, which yields me a sure profit of 3 a 400 Rs. per mensem. In this Way tho' I am laying by monthly a little money, I am not making a Fortune. ${ }^{9}$

His final comment reveals that for him-as for many of those employed by the East India Company- "making a fortune" was a high, if not primary, ambition.

In 1773, the approximate time that the letters were written, Anderson's position was that of Persian Translator to Middleton at Murshidabad. ${ }^{10}$ But he had his eye on the more lucrative posting of Persian Translator to the ambassador, whom the Company was planning to appoint to the court of Shuja-ud-Dawla, the ruler of Awadh. He believed there was a good possibility of obtaining the post due to the substantial influence of an unidentified "Mr. Graham," and to a majority of the Council being his friends. Anderson had also earned the trust and gratitude of Hastings by doing some translation work for him-"I have lately given the Governor great Satisfaction in translating a very long and favourite Performance of his into 
Persian." ${ }^{11}$ To his disappointment, however, the post was awarded to another.

It was during this time that Anderson's assistance was requested by Gobind Ram for a recommendation to "Mr.Johnson Sahib," who was probably Richard Johnson (1753-1807) newly arrived in India on 4 June 1770 as a Writer. ${ }^{12}$ With his appointment as Assistant to Hastings in 1772 , Johnson became active in the social life of Calcutta and participated in the intellectual and artistic pursuits of his contemporaries, especially in the amassing of a large collection of Persian miniatures. ${ }^{13}$ For Gobind Ram to request a recommendation to such an influential person who had the ear of the Governor-General would seem reasonable. In 1780 Johnson would be sent to Lucknow, where for the next two years he served as the assistant to the Resident, Nathaniel Middleton. In the latter's absence, Johnson was given responsibility for discharging the duties of Resident, but was recalled in 1782 for abusing his trust. ${ }^{14}$ Lucknow had increased in political, as well as cultural, importance after Asaf-udDaula relocated his capital there upon acceding in 1775 to the title of Nawab of Awadh. While in Lucknow, Johnson became acquainted with Tafazzul Hussain Khan, who is also mentioned in Letter "A," and they developed a friendship that continued after Johnson's return to Calcutta. In 1784 he became the Resident at the Nizam's court in Hyderabad; but the problems noted at Lucknow followed him, causing him to resign as a result of charges laid by the minister of the Nawab Vazir of Awadh. He returned to England in 1790 with two chests containing oriental manuscripts and paintings he had collected in India. ${ }^{15}$

\section{Tafazzul Hussain Khan (1727-1800)}

Gobind Ram complained in Letter "A" that when he arrived in Calcutta his former friend, Tafazzul Hussain Khan, who was now in a high position, paid no attention to him. Although it is not clear what position Tafazzul Hussain held in 1772, he does provide another fascinating illustration of the relationships between British and Indian elites in the late $18^{\text {th }}$ century. His full name was Allāma Tafazzul Husain Khān Kashmīri, popularly known as the Khān-i Allāma. His grandfather was Karamu'llah who served as vakil (ambassador) to Mu'inu'l-Mulk, governor of Lahore. ${ }^{16}$ Tafazzul Hussain was born in Sialkot, and at the age of thirteen or fourteen moved to Delhi where he studied under its leading teachers. Four years later, the family moved to Lucknow, where he was admitted to the seminary of Mullā Hasan of the Firingi Mahal. ${ }^{17}$

In his illustrious career, Tafazzul Husain Khan held a number of influential positions under the Nawabs of Awadh - discussed later in this article. ${ }^{18} \mathrm{He}$ was initially appointed by the Nawab-Wazir of Awadh, Shuja-ud-Dawlah, as mentor and tutor to his second son, Sa'adat Ali Khan. ${ }^{19} \mathrm{He}$ accompanied Saadat 'Ali Khan to Allahabad in 1769 where the young noble was vice-minister to the Mughal Emperor, Shah Alam. ${ }^{20}$ A year after the death of the Shuja-udDawlah, in 1775, Saadat Ali Khan participated in an abortive assassination plot against his older brother, Asaf ud-Daulah, who had succeeded his father as Nawab. As a result Tafazzul was forced to flee with the young prince. ${ }^{21}$ In a September 9, 1777 letter to Mr. Middleton, Saadat Ali Khan requested permission to return to his brother's capital in company with Tafazzul. ${ }^{22}$ Not surprisingly, his brother turned down the request. ${ }^{23}$ Tafazzul Khan, with the assistance of his brother, Rahmatullah Khan, left the young prince's service when he returned to Lucknow. Thus a few momentous years after Gobind Ram's complaint about Tafazzul, their situations had reversed. Tafazzul's career suffered a series of setbacks because of his close alliance with the unsuccessful Saadat 'Ali Khan, while Gobind Ram gained an influential position under the victorious brother, Asaf ud-Daulah.

In September, 1779, through the influence of Major William Palmer (1740-1816), who was 
Hastings' military secretary and later replaced David Anderson as Resident in Mahadji Sindhia's court in Gwalior, Tafazzul was appointed by Hastings ${ }^{24}$ as vakil of the Rana of Gohad, Chhatar Singh, in settling the terms of a treaty between him and the Company. ${ }^{25}$ When he arrived in Gohad, Tafazzul quickly gained the full confidence of the Rana. Among other things, Tafazzul reported back to Hastings about the defeat, with British assistance, of the Mahrattas encamped near Gohad. ${ }^{26} \mathrm{He}$ also wrote to his brother Rahmatullah about efforts to forge an alliance between Hastings and the Rajas in the area, with a view of making them dependent on the English sarkar ("head of affairs"). ${ }^{27}$ In return, Hastings had Tafazzul accompany David Anderson in 1782 during negotiations with the Maratha chief, Mahadji Sindhia. ${ }^{28}$ The intrigues of Tafazzul and Haider Beg Khan at the Awadh court in Lucknow, during 1784, contributed to $\mathrm{Mr}$. Johnson's removal from office. ${ }^{29}$ After Gobind Ram's death in 1788, Tafazzul succeeded him as the vakil or diplomatic representative of Asaf ud-Daulah in Calcutta - their careers yet again intersecting with one another. ${ }^{30}$

\section{Hastings in Bengal}

One event in the correspondence can be verified by other sources, namely the visit of GovernorGeneral Hastings to Benares in 1773. In letter "B," Ram describes the event from the perspective of one accompanying "Milton Sahib" - Samuel Middleton (1736-1775) - to Plassey to meet with Hastings. ${ }^{31}$ Middleton and his entourage including Gobind Ram travelled with Hastings to Madapur ("Madhubpur" in the translation) where they halted for four or five days, and a Durbar or official reception was held. On the $17^{\text {th }}$ of Rabi' al-Thani, Governor-General Hastings departed for "the west" on ships departing from Sadiq Bagh. The account of this meeting enables the positive dating of the letter. In his diary, Hastings recounts his trip to Benares to meet with the Nawab of Awadh, Shuja-ud-daulah in the summer of 1773 - setting out from
Calcutta on June 24, 1773, quitting his boats at Augerdeep, and proceeding by land to Plassey. ${ }^{32}$ There he was met by Middleton and the Nawab of Bengal, Mubarak-ud-daulah. Not surprisingly, no mention is made of Gobind Ram who was a minor attendant to Middleton. Hastings writes that he proceeded the next morning to "Moidapoor," arriving on July 4, for an official visit with Munni Begum, widow of Mir Jafar and guardian during the Nawab's minority. On July 9 Hastings continued his journey from "Saddoc Baug" where boats were awaiting him, and continued on to Benares. These diary references provide independent confirmation of letter " $\mathrm{B}$ " since Gobind Ram stated that he accompanied Middleton on this journey "a few days ago" - on 17 Rabi' al-Thānā, the equivalent of 8 July 1773 - giving as close a match as could be expected. ${ }^{33}$ Hastings' trip to Benares is also mentioned in the Catalogue of Persian Correspondence, with relevant letters mentioning Hasting's departure from Calcutta on 4 Rabi' II (June 24 or 25) and his arrival at Murshidabad on route to Benares on July $5 .^{34}$

Gobind Ram's encounter with Hastings is also mentioned in several letters to him from Antoine-Louis Henri Polier, dated between 8 Rabi' I 1187 (May 30, 1773) and 22 Ramazan, 1187 (December 7, 1773) - at about the same time Ram wrote to Anderson. ${ }^{35}$ In earlier letters, Polier indicated that Gobind Ram had requested a letter of reference to Middleton, which was supplied. ${ }^{36}$ At the time, Gobind Ram was residing in Calcutta. In a letter, dated 12 Rabī 'II from Lucknow, Polier wrote, "I have received your letter in which you have mentioned about your meeting with the Governor..." This would appear to be two days before Hastings' arrival at Murshidabad, where he met with Middleton accompanied by Raja Gobind Ram. The events occurred too closely to one another to be ignored. Considering that within two years of these letters Gobind Ram would be appointed Asafud-Daula's vakil to Hastings in Calcutta, we can speculate that Polier may well have played a role 
in promoting Gobind Ram's cause in the Nawab's court at Lucknow.

The simple recounting by Gōbind Rām of this meeting gives no indication of the political undercurrents motivating Hastings' journeys. Mubarak-ud-daulah, who met Hastings at Plassey, had in 1770 at the age of eleven or twelve succeeded as Nawab of Bengal his brother Saif-ud-daulah, who had died in an outbreak of smallpox which, together with a famine, was causing great devastation throughout the region. ${ }^{37}$ Because the new Nawab was a minor, a senior bureaucrat, Muhammad Reza Khan was appointed guardian. Munni Begum, mentioned by Hastings in his diary, was the widow of Mubarak-ud-daulah's father, Mir Jafar, and the mother of the previous Nawab (though not of Mubarak). She had exercised considerable influence in the Bengal court. But with the death of her son, she lost her power, and expressed her resentment against Reza Khan in complaints to the British later that year. ${ }^{38}$ In 1772 , when Hastings was appointed Governor-General, Reza Khan sought to establish friendly relations with the new administration, but his overtures were coolly received, and within a month he had been arrested and transported to Delhi, without any clear charges being laid. ${ }^{39}$

On April 27, 1772, while serving an assistant to the Murshidabad Council of Revenue and its chief Samuel Middleton, David Anderson had been deputed to arrest Muhammad Reza Khan. ${ }^{40}$ In an October 18, 1772 letter to London, Anderson described how Khan had been very cooperative when he and the others were arrested, and had their effects seized. ${ }^{41}$ At the time of writing, the arrested men were under restraint in Calcutta, awaiting an enquiry into their conduct by a Committee, consisting of Davies, Lawrell, and Graham. From the charges that were eventually laid, it would appear that the British East India Company was using Reza Khan as a scapegoat for some of its own economic troubles. Hastings saw, however, in the arrest and delayed trial of this powerful political figure an opportunity to advance his own ambition and gain effective financial control of Bengal. ${ }^{42}$ Reza Khan's trial commenced the following year, and ended in 1774 with his acquittal of all charges. Much later, in 1780, he was restored to his post as Naib Nazim. ${ }^{43}$ By then Hastings had been able to set up his new system in Murshidabad, with Middleton as Resident, and Munni Begum as guardian of the young Nawab. ${ }^{44}$ It was in this context that Hastings visited Middleton, Mubarak-ud-daulah, and Munni Begum in the summer of 1773 when he was on his way to Benares.

\section{The Nawabs of Awadh}

Warren Hastings went to Benares in order to meet with Shuja-ud-Daulah, the Nawab of Awadh, a Mughal province bordering Bengal to the north-west. Shuja-ud-Daulah had allied himself with the Nawab of Bengal and the Mughal Emperor against the British, but had been defeated at Buxar in 1764, and again the following year at Kura. When the Marathas began threatening, he sought help from British troops, as the British shared his antipathy to the rise of Maratha power. The Mughal Emperor Shah Alam had been defeated by the Marathas near Delhi in 1772, and as a result had ceded to them the territories of Korah and Allahabad. ${ }^{45}$ In 1773, British troops joined those of Shujaud-Daulah in successfully stopping the Maratha advance into Awadh. But the Nawab of Awadh had greater ambitions than simply stopping such an invasion; he now intended to subjugate the region of the Rohilkhand and sent a proposal regarding its annexation to Hastings.

In view of these events, Hastings set out in June, 1773, stopping to meet with Middleton and the Nawab of Bengal en route. When Hastings arrived at Benares, he and Shuja-ud-Daulah held talks concluding in the treaty of September 7, 1773. According to its provisions, the districts of Korah and Allahabad were sold to Shuja-ud- 
Daulah, with British troops promising - for a sum - protection of the Nawab's territories. Other agreements reached at the conference included a promise of British help to the Nawab in conquering the Rohilkhand, in exchange for receiving a British Resident at his court ${ }^{46}$ Gobind Ram would benefit directly from increased cooperation between the Awadh court and the British, when three years later, after the death of Shuja-ud-Daulah, he was appointed vakil to the British by the Nawab's successor.

\section{Gobind Ram as Vakil}

Gobind Ram was appointed vakil on Apr. 5, 1775 by Nawab Asaf-ud-Daulah who had succeeded his father Nawab Shuja-ud-Daulah in the Vizarat after the latter's death a few months earlier. ${ }^{47}$ Various letters describe Ram's services, such as making representations, and carrying messages and presents between the Nawab and the Governor-General. ${ }^{48}$ Hastings described him in further correspondence as a capable man who always tried to promote good understanding between the Nawab and the Company. ${ }^{49}$

The vakil was an institution used by Mughal officials to represent their interests as personal agents at the Imperial court, as well as in other regional courts. Vakils were normally recruited from "the Islamicized elite of scholars and administrators who traditionally served in such positions across India." ${ }^{50}$ They appeared in court, representing their masters before the ruler in formal rituals, and were ranked according to status. Titles were bestowed by both the ruler and the vakil's immediate master. In 1777, Nawab Asaf-ud-Daulah sent a khilat (robe of honour) to the Governor-General requesting him to invest Gobind Ram with it. ${ }^{51}$ In October, 1778, the Nawab requested the Governor-General to relinquish, in favour of Ram, a land grant in the district of Arwal. These acts were done in recognition of Gobind Ram's devoted and loyal service to the Nawab and the Company, and in also consideration of friendship between the two. ${ }^{52}$ Gobind Ram was instrumental as well in negotiations between the East India Company and the Maratha leader, Madhava Rao Sindhia. ${ }^{53}$

In addition to functioning as vakil of the Nawab Asaf-ud-Daulah of Awadh, Ram also served as vakil of the Rajputana Chiefs and Raja Sarnet Singh. ${ }^{54}$ As well, during March/April, 1785, he was appointed vakìl of the Prince Jahāndār Shah, eldest son of the Emperor of Delhi, ${ }^{55}$ The prince was an exile from his father's court and living in Lucknow, "on the bounty of the Nawab Vazir under British protection." ${ }^{\text {" On }}$ this occasion, the current Governor-General described Gobind Ram as"a faithful and trustworthy servant of His Majesty and the Nawab Vazir and a well-wisher of the Governor-General." 57

Gobind Ram's role was much more than a mere postman delivering letters, but required skills of diplomacy and tact, in order to convey accurately the opinions of powerful and ambitious leaders in a context where respect and etiquette were highly prized. There are many, albeit brief, mentions of his work as a vakil, shuttling between the British administrators in the Bengal and the ruler of Awadh. There are numerous letters to him from Nawab Asaf ud-Daulah of Awadh and Warren Hastings. ${ }^{58}$ Other letters make references to him in his role as vakil or ambassador, serving the Vizier of Awadh and, seemingly, the GovernorGeneral as well. ${ }^{59}$ One letter written by Ram on Tuesday, 17 Ramazan 1196 A.H. [August 27, 1782] in the same collection is instructive. ${ }^{60} \mathrm{He}$ described himself as being employed in Calcutta for eight or nine years - since 1773-1774, when his letters " $\mathrm{A}$ " " $\mathrm{B}$ " and " $\mathrm{C}$ " were written. David Anderson is mentioned by Ram as sending reports to the Governor General from the Sindhia's camp, which precluded his being sent to the Nawab's court, resulting in Bristow being sent instead. Gobind Ram's assistance in organizing such matters was noted with appreciation. ${ }^{61}$ For instance, he was asked by Hastings to deliver a letter explaining his position on the matter to the Nawab. Gobind Ram returned subsequently 
with a letter expressing displeasure at Hastings' interference in the Nawab's affairs. ${ }^{62}$

In a 1787 letter to John Shore, Warren Hastings expressed his confidence in Gobind Ram who, with Tafazzul Hussain, could give positive testimony in the impending impeachment trial in England. ${ }^{63}$ Although two letters written by Gobind Ram while vakil for Nawab Asaf-udDaulah - summarized in Calendar of Persian Correspondence, footnote 2 - were entered in their entirety in the minutes of Hastings' trial, they were used to support the arguments for the prosecution. ${ }^{64}$ In a letter written on December 26, 1787, Gobind Ram indicates that he had been ill and under treatment. In his absence, Lala Bhawani Parshad was to serve the GovernorGeneral. ${ }^{65}$ The following year, Gobind Ram died, and Tafazzul succeeded him as vakil.

\section{Other names mentioned in the letters}

In Letter "B," reference is made to James Lawrell and Tom (or John) Graham as "Lord Sahib" and "Tom Karim Sahib." James Lawrell had been nominated along with John Graham to the Murshidabad Council of Revenue when it was formed in July, $1770 .{ }^{66}$ In a letter to Muhammad Reza Khan in September, 1770, Hastings had written that because of the importance and difficulty of the work at Murshidabad, the functions of the Resident were too heavy for one man and were being entrusted to a board of four, including Lawrell and Graham. ${ }^{67}$ By 1773 , the council in Murshidabad had been dissolved, and Lawrell was serving on the governing council in Calcutta. Hastings appointed him to take possession of Korah and Allahabad. ${ }^{68}$ Lawrell was present during Hastings' visit to Benares in 1773 - as discussed earlier. ${ }^{69}$ The reference to "Graham" could be to either John Graham or his brother Tom. ${ }^{70}$ John Graham worked closely with Lawrell in Murshidabad, and had been deputed by Hastings to communicate the intentions of the East India Company to Reza Khan along with his response, after being arrested in $1772 .^{71}$
His brother Tom Graham was also associated with Lawrell. ${ }^{72}$ In 1773 , Tom assisted Lawrell on the deputation to Korah. ${ }^{73}$ Tom was also closely associated with David Anderson in business. ${ }^{74}$ Both "Mustepha" and Gobind Ram refer to David Anderson and Lawrell. ${ }^{75}$ In addition, David Anderson - as an assistant to the Murshidabad Council - would have been well acquainted with Lawrell and John Graham, who were also members , and with Middleton who was Council Chief before its being disbanded - about a year before the letter was written.

After serving under Middleton, Anderson received other postings from Hastings, such as negotiating the end of the first Mahratta war in $1782,{ }^{76}$ when he was accompanied by his brother, Lieut. James Anderson, mentioned by Tafazzul as well as by Gobind Ram in Letter "B."77 David Anderson remained with Madhava Rao Sindia as Political Resident until 1785 when he returned to Britain on the same ship as Warren Hastings, whose life-long friend he remained. ${ }^{78}$ In 1780 Anderson purchased the Estate of St. Germains, East Lothian, Scotland which has passed down through his descendants. He married Christian, daughter of Robert Findlay, of Drummore on Aug. 14, 1788, and had two sons, David and Warren Hastings. ${ }^{79}$ Anderson gave 113 volumes of Oriental manuscripts to Edinburgh University, listed in A Descriptive Catalogue of the Arabic and Persian Manuscripts in Edinburgh University Library, by Mohammad Hukk. ${ }^{80}$ A large quantity of Anderson family papers remains with the estate, Anderson of Northfield (formally of St Germains and Bourhouse) ${ }^{81}$

At the direction of Hastings, David's brother Lieut. James Anderson, mentioned by Gobind Ram in Letter "B" as "your younger brother," helped translate Muslim legal literature. His associate in this translation, Charles Hamilton, took over the project when James became engaged in negotiations with other Indian rulers. Hamilton paid tribute to James, in their translation of the Hedáya, as "a gentleman whose 
eminent literary qualifications for accomplishing such an undertaking could only be excelled by the solidity of his understanding, and the goodness of his heart." 82

\section{THE LETTERS COME TO MCGILL}

Raja Gobind Ram's letters to David Anderson were deposited at the library of McGill University in 1895 - their location in the intervening time remaining a mystery, with sparse clues. Accompanying notes and some penciled notations on the translations indicate that the letters came into the possession of J. K. Oswald, who then offered to them for sale to McGill. One of the notations indicates that the translations were made by a munshi some considerable time after the letters were written.

The sale offer of five dollars to the McGill Library was made on November 14, 1895, in a note written on the reverse of a "Borrower's Form" of the McGill College Library: "If you still would take the letters for Sum of $\$ 5.00$ send amount to Metropolitan Club \& oblige. Yours, J. K. Oswald. 14.11.95." This note was addressed to Charles $\mathrm{H}$. Gould, Esq., McGill University Librarian, 18931919. Accompanying the translation is a notation, in a similar hand, "My Moonshee tells me that the letters are worth a lot, the paper being hand made which accounts for its good Condition, the writing he had some difficulty in translating, as the letters are somewhat of an old style." Although these notes suggest that Oswald had been in India and that his own munshi undertook the translation, it is more likely that he is merely quoting someone else. There is no record of J. K. Oswald ever having been to India, though his son William did spend a number of years there. As no connection between the Anderson and Oswald families in Scotland has been discovered, it seems reasonable to assume that the letters remained in India during the intervening 120 years. Further correspondence located in the McGill archives includes the following letter dated November 25,
1895 from Gould to Oswald: “ My dear Sir:- I have yours of the $14^{\text {th }}$, in regard to the Hindostani manuscripts, and will give you a definite answer in the course of a few days. Meantime, the letters are perfectly safe here. ${ }^{\prime 3}$ Oswald responded on November 28 in a letter written on Metropolitan Club letterhead: "My dear Mr. Gould. Many thanks for yours $25^{\text {th }}$ instant - I know the Hindustani manuscripts are perfectly safe in your keeping - that was chiefly my reason for leaving them with you - Kindly do the best you can with them for me $\&$ let me know results at your convenience, at above address." ${ }^{4}$

At the time, there were two J. K. Oswalds listed in Lovell's Montreal Directory, Capt. J. K Oswald at 7 Victoria, and James K. Oswald, bookkeeper, at $121 \mathrm{St}$. Matthew - the former being the father of the latter. ${ }^{85}$ The signature on the note to Gould matches that of Capt. James Kidd Oswald in the church register for the baptism of his son William Whitehead Oswald. By comparison, the signature of the younger James K. Oswald, on the 1901 marriage certificate of William W. Oswald differs considerably from that on the note to Gould. One is, therefore, led to conclude that it was J. K. Oswald Sr. who sold the letters to McGill.

\section{James Kidd Oswald (1850-1899)}

James Kidd Oswald, son of Henry Campbell Oswald and Eliza MacKenzie, arrived in Montreal from Aberdeen, Scotland, along with his older brother, William Robert Oswald (18481899) sometime in $1866 .{ }^{86}$ Reminiscent of David and James Anderson in Bengal one hundred years previously, James and William Oswald had Canadian business, political, and military careers. The brothers worked as general managers of the Scottish Fire Insurance Company and Scottish Provident Institution, under the directorship of Alexander Mitchell. ${ }^{87}$ Both also took an active part in Montreal's military life: James serving as lieutenant in the Victoria Rifles during the Fenian raid on Eccles Hill in 1870, and William serving 
as lieutenant in the Montreal Garrison Artillery during the battle at Huntingdon a few days later. ${ }^{88}$ James was active in sports, particularly golf. As a member of the Royal Montreal Golf Club, the first Canadian golf club, he participated in an 1876 competition between the Montreal and Quebec City clubs - the first North American golf match. ${ }^{89}$

In Montreal, Robert and James established the firm of Oswald Brothers, an insurance and stock brokerage firm, which they managed together until 1875 when James sold his share to start the Merchants' Marine Insurance Co. When this venture failed because of large losses sustained in the Maritime Provinces, he moved to Western Canada around 1882, settling first in Manitoba before moving on to Calgary. For his part, William continued the Oswald Brothers firm, which was the general agent for the City of London Insurance Company. In 1874 he became one of the founding members of the Montreal Stock Exchange. Both William and James had been members of the earlier Board of Stock Brokers. ${ }^{90}$ When James returned to Montreal around 1893, he again took up business, working as insurance broker and promoter until his death in $1899 .{ }^{91} \mathrm{He}$ joined with J. E. E. Dickson, manager of the Law Union and Crown Insurance Company, in conducting city business. ${ }^{92}$ It was during this time that James offered to sell the Persian manuscripts to McGill.

The ten year sojourn of James in Western Canada reveals an even more varied career. $\mathrm{He}$ resided briefly in Manitoba before establishing himself in the frontier settlement of Calgary, North West Territories. In an 1882 announcement of provincial appointments, the Winnipeg Times stated that James Kidd Oswald of Souris had been appointed a Justice of the Peace for the Province of Manitoba. ${ }^{93}$ Within six months, however, he had made his way to Calgary, becoming one its earliest residents. In the spring of 1883, the new settlement on the Bow River had a population of less than 100, but would grow rapidly over the next few years. By August, the Canadian Pacific Railway reached the east bank of the Bow where James established a business office, Real Estate and Land Agent, and General Commission Broker, Calgary, N.W.T. ${ }^{94}$

James Oswald had high hopes that success in business or government service would enable his family to relocate to the West. His eldest son, $\mathrm{H}$. Campbell Oswald, did join him in 1883. Letters indicate that a number of influential friends were actively lobbying on James' behalf for a government position, once again reminiscent of the letters written by Gobind Ram to David Anderson. W. B. Scarth, managing director of the North-West Land Company and influential political organizer for the Conservative party in Ontario and Manitoba, wrote three letters to Prime Minister Sir John A. Macdonald, requesting that Oswald be appointed to some post in the North West Territories. These letters refer to prominent Conservative Members of Parliament such as the A. P. Caron, George A. Kirkpatrick and Col. A. T. H. Williams who would be prepared to vouch for Oswald. ${ }^{95}$ Scarth was promoting James because "He has a nice gentlemanly manner and would, I think be well suited for the position of government guide or something in connection with the Indian Department." 96 After meeting with James in Calgary during July 1883, Scarth recommended his appointment as Land Agent or Registrar at Calgary. ${ }^{97}$ These efforts were rewarded later that year when James was appointed Justice of the Peace, Notary Public, and Issuer of Marriage Licences for Calgary. ${ }^{98}$ The following year, he was also appointed Guardian under the Ordinance for the Protection of Game, while his son, H. Campbell Oswald, was appointed Notary Public. ${ }^{99}$ Two years later, another plea to the Prime Minister was made by a friend of James' wife, Alice Ann Oswald, by Charlotte Stephen - wife of George Stephen, later Lord Mount Stephen - a leader of the Montreal business community, founding President of the Canadian Pacific Railway, and an advisor to Macdonald. 
In requesting the postmastership of Calgary for James, Mrs. Stephen wrote that "Mrs. James Oswald is a very old friend of mine, and this appointment would enable her and her children to live there. He is quite steady and though not a prodigy has brains enough for the office."100

Apart from political appointments James Oswald played a direct role in the political life of Calgary, being nominated as a candidate for town council - but not elected. Along the way to becoming a province in 1905, the District of Alberta was created in 1882 within the NorthWest Territories, with Calgary in 1884 being the first electoral district. James put his name forward immediately as a candidate for a seat on the North-West Council based in Regina. His speech at the candidates' meeting focused upon demands that the railway companies free up their land for settlement, take more responsibility for preventing prairie fires, and provide safe railway crossings. ${ }^{101} \mathrm{He}$ also pushed for greater provincial representation and recognition in Ottawa, and an end to the federal government practice of using the West for patronage appointees from the East! His main opponent was J. D. Geddes, a rancher who focused on the concerns of cattle farmers in the region surrounding Calgary. Although James obtained a majority of votes cast within Calgary, Geddes won the election by a majority of 12 out of 188 votes cast, having received almost all the votes from the rural regions. ${ }^{102}$ The Calgary paper that supported Geddes, The Nor'-Wester, carried a detailed account of the contest and subsequent victory speeches, and accused James' supporters of intimidation and interference. ${ }^{103}$ James responded by submitting a petition to the Territorial Council, charging that irregularities in posting the voters' list, and permitting illegal votes, had resulted in Geddes' victory. ${ }^{104}$ After considering the petition, and legal ramifications of questioning the results submitted by a returning officer, the Council accepted the election results.

In spite of these setbacks, James Oswald continued to be politically active, participating in a mass rally towards the end of the year when he moved a motion requesting that the federal government "make the North-West Council a purely elective body, with fuller and larger legislative powers than those now enjoyed by the Council; until the time shall arrive when the different Provisional Districts shall be erected into separate Provinces with their own Local Legislatures." ${ }^{105}$ The following spring, James led a delegation to Ottawa for interviews with the Minister of Public Works to discuss the construction of bridges and a court house in Calgary, as well as more effective ways of controlling the illicit whiskey trade through granting more licences for brewing beer made from locally grown barley and native wild hops ${ }^{106}$

James Oswald was in Calgary when Native and Métis troubles in the Carleton-Duck LakeBatoche region turned into the Riel Rebellion of 1885. James was recruited by Samuel Benfield Steele - known popularly as Sam Steele of the North-West Mounted Police - to be Captain in charge of a troop of scouts, Steele's Scouts. They accompanied General T. B. Strange and his forces as they marched north to Edmonton, and then east down the Saskatchewan River to meet up with General Middleton's forces marching west from Winnipeg. In a combined action, they defeated Big Bear, the one remaining rebel leader after Louis Riel's and Gabriel Dumont's defeat at Batoche, and Chief Poundmaker's surrender at Fort Carlton ${ }^{107}$ - with military engagement limited to several skirmishes around Fort Pitt. ${ }^{108}$ Following conclusion of the campaign, James held a commission as Lieutenant in the Mounted Infantry Corps, stationed at the Barracks in Ft. Osborne, Winnipeg. ${ }^{109}$

His brother, William R. Oswald, who had continued his association with the Garrison Artillery in Montreal, took its command as Lt.Col. in 1881. He led his brigade to Winnipeg in 1885 as part of the force sent out to suppress the Rebellion, but did not participate in any engagements. Instead, his brigade guarded Louis 


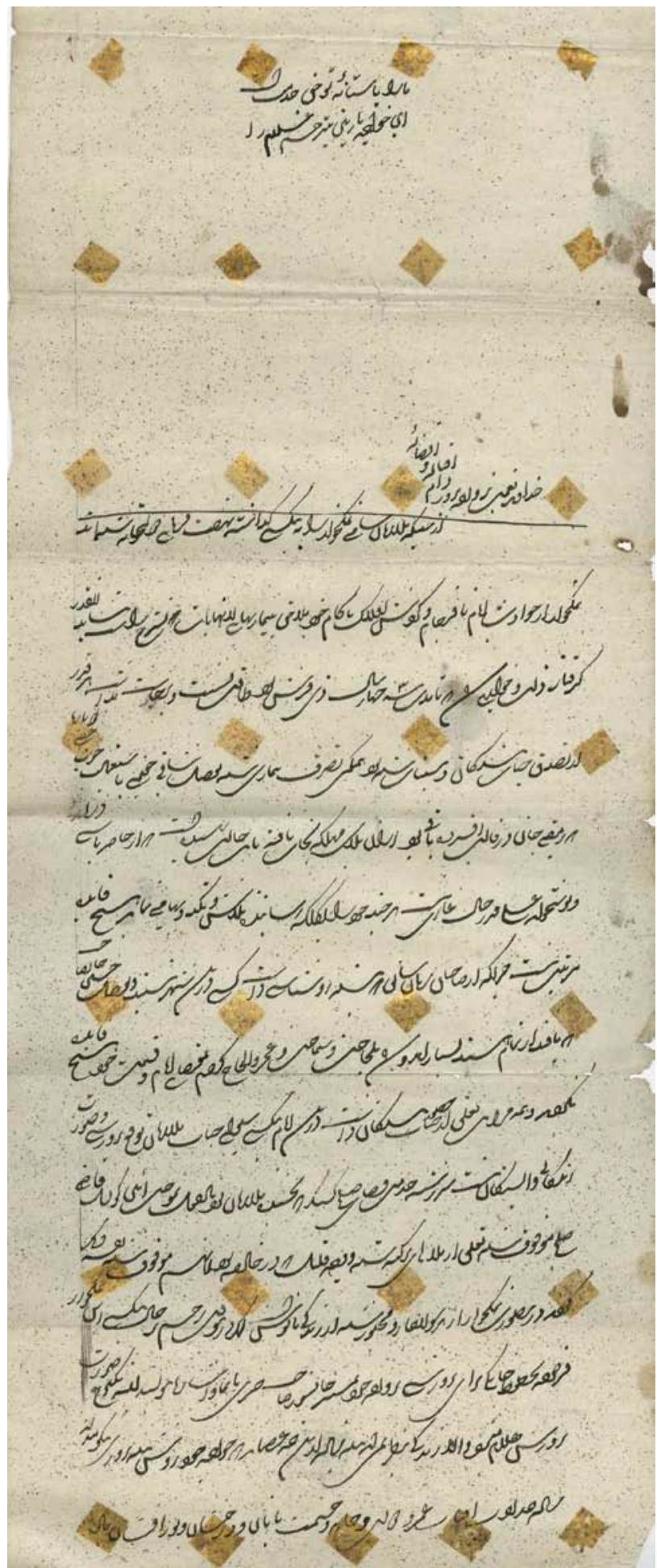

Letter A of MS 971. Manuscript Collection, Rare Books and Special Collections Division, McGill University Library. 


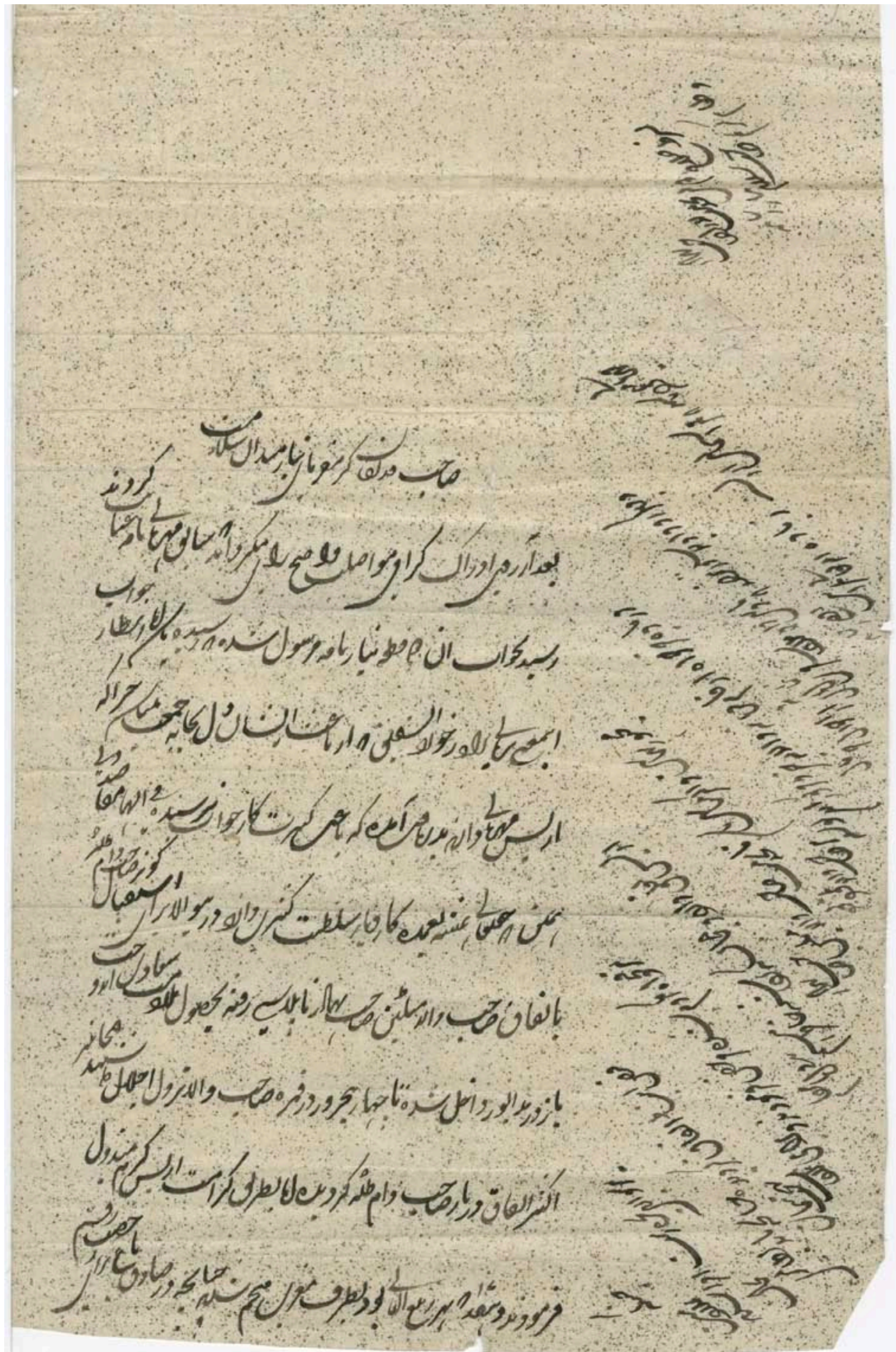

Letter B of MS 971. Manuscript Collection, Rare Books and Special Collections Division, McGill University Library. 


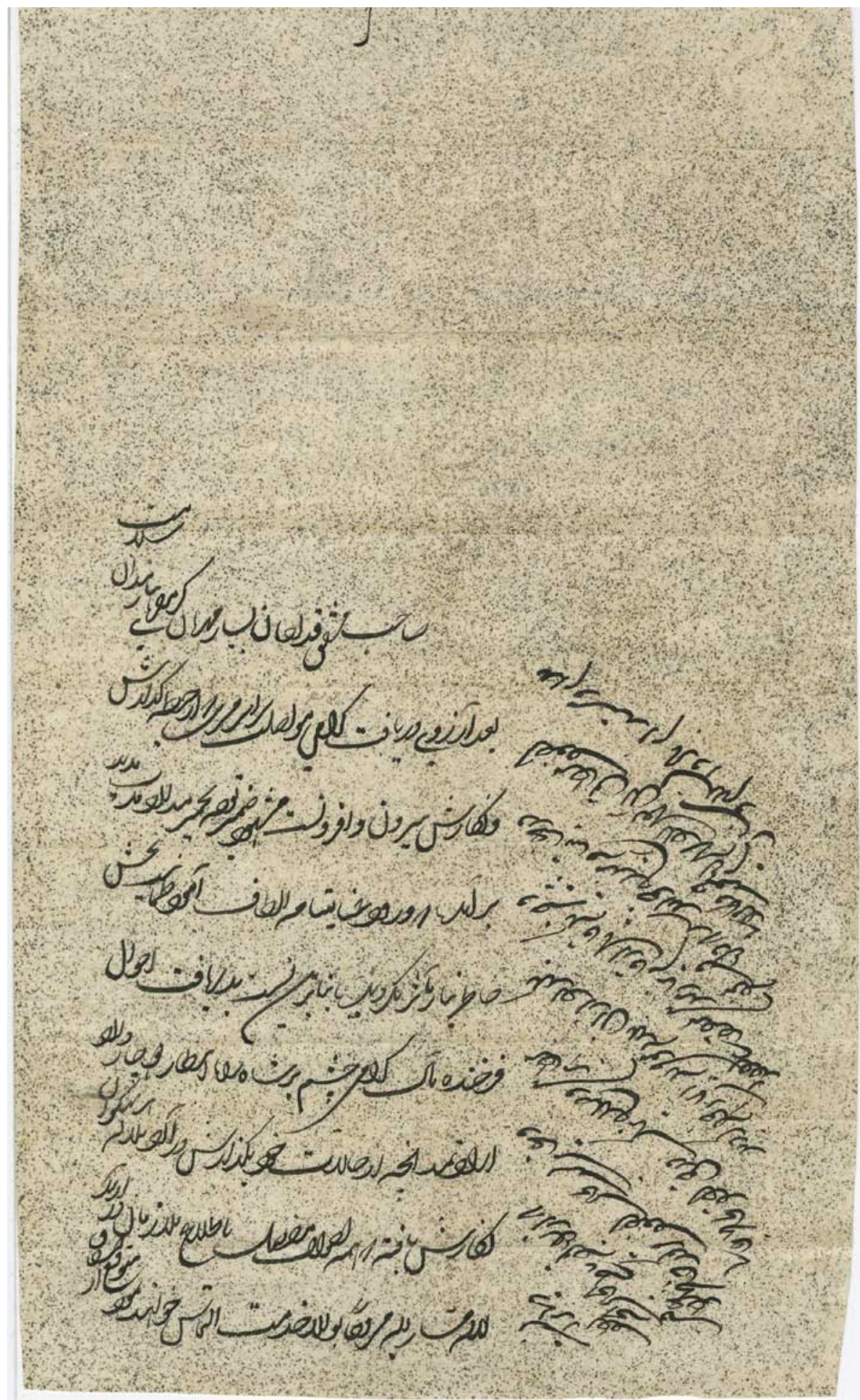

Letter C of MS 971. Manuscript Collection, Rare Books and Special Collections Division, McGill University Library. 

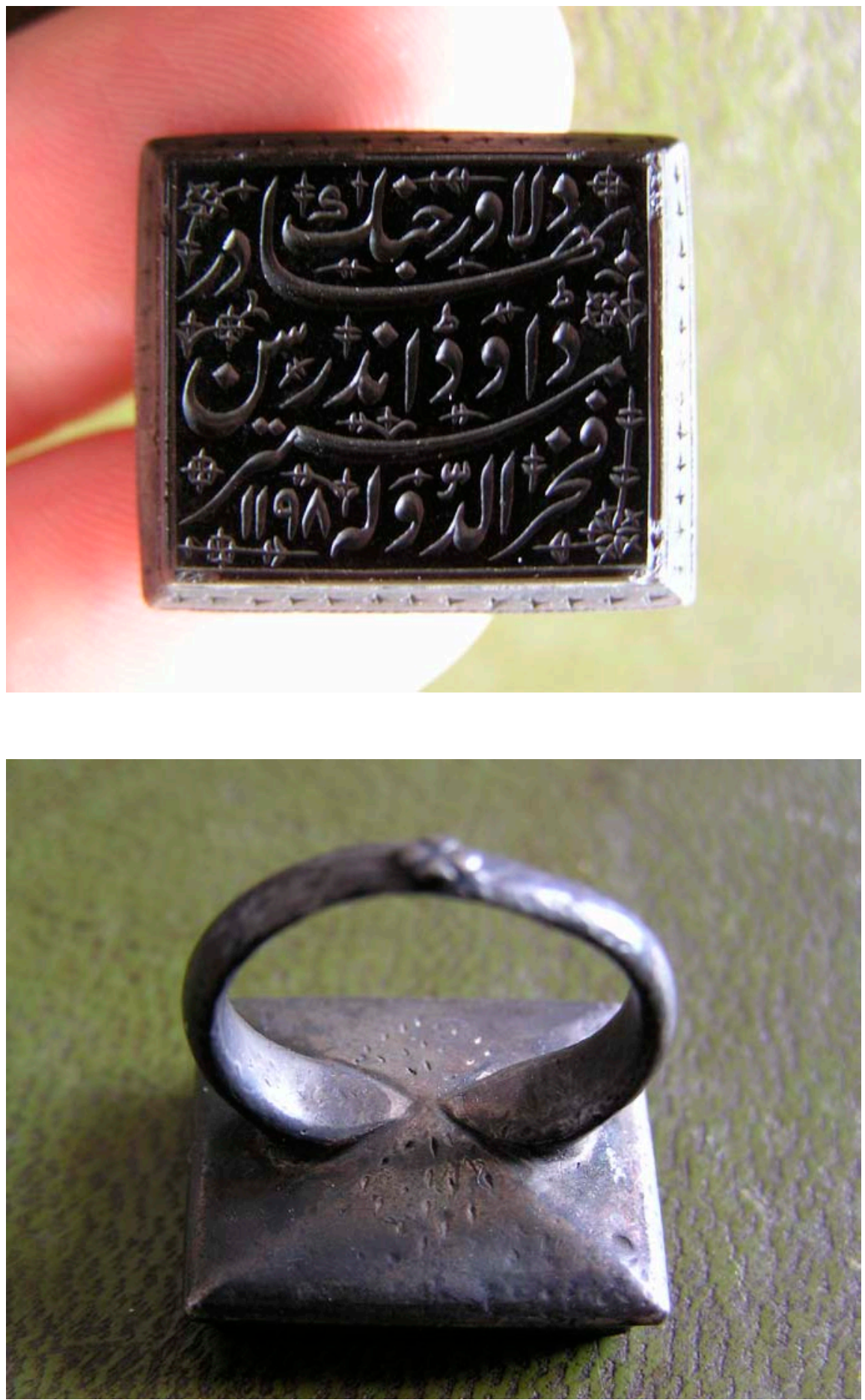

The seal of David Anderson with the following inscription in Persian: "Bahadur Dilawar Jang, Mister Daud Andersin, Fakhr ud-Dawla, 1198." Anderson Collection, Anderson of Northfield, Scotland. 


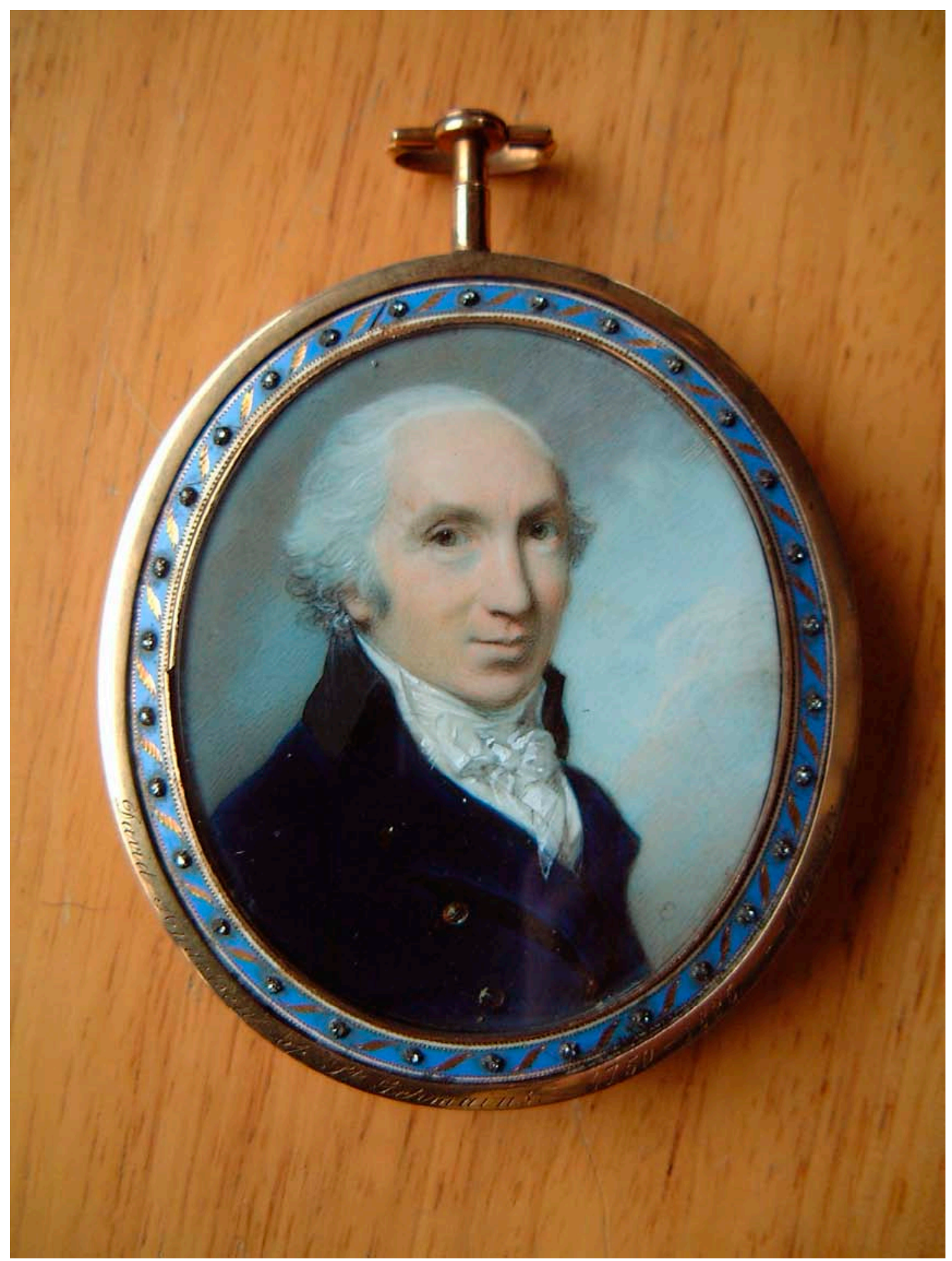

A portrait miniature of David Anderson.

George Engleheart, Anderson Collection, Anderson of Northfield, Scotland. 
Riel and his councillors to thwart any rescue attempt. ${ }^{110}$ Back in Montreal, he continued his activity with the military, organizing an artillery team to compete in England, and being elected president of the Dominion Artillery Association in 1887.

\section{Family of James Kidd Oswald}

In the fall of 1870, after participating in the campaign against the Fenian raids, James Oswald married Alice Ann Whitehead, daughter of William Thomas Whitehead and Isabella Ross, of Montreal. ${ }^{111}$ The church registers indicate that 10 children were born to James and Alice in the next 12 years, only four of whom survived three sons, Henry Campbell (b. 1871), William Whitehead (b. 1873), and James Kidd (b. 1874), and one daughter, Isabel Julia (b. 1879). Two sons died in infancy, and two sets of twin girls did not survive childhood, the oldest living to the age of 10 . The 1881 census gives the following composition of the household ${ }^{112}$

- James Oswald, age 30, born in Scotland, Presbyterian, Scotch, Merchant

- Alice Oswald, age 28, born in Quebec

- Henry Oswald, age 10

+ William Oswald, age 8

- James Oswald, age 7

+ Isabella Oswald, age 3

- $\quad$ Alice Oswald, age 1

- Ellen McDonald, age 38, Catholic, Servant

- Kate McCarthy, age 40, born in Ireland, Catholic, Servant

- Mary O’Neil, age 42, Catholic, Servant

- Ida Backer, age 16, Baptist, German, Servant
After twin girls were born on 31 Oct. 1882, James Oswald was apparently absent from both their christening and their funeral a month later, most probably because he had already moved West. ${ }^{113}$ Left to rear the children alone, Alice's siblings came faithfully to her aid. Her unmarried sister Julia Whitehead moved in, remaining well into the following century. Her brother, Colonel Edward A. Whitehead, (18451912) also assisted, especially in giving care and direction to the three boys. ${ }^{114}$ James' brother William continued living in Montreal, and in 1876 married Graham Campbell Greenshields, daughter of John G. Greenshields and Elizabeth McCulloch Black. ${ }^{115}$ William and Graham had two children, a daughter Jean Greenshields (b. 1877) and a son Malcolm Campbell (b. 1879). William died after a short illness in 1899 while visiting his mother, during a trip to Britain. ${ }^{116}$

James Oswald returned to Montreal around 1893, but prolonged absence from his family seems to have resulted in an estrangement from his wife, as he is listed with a separate address in directories of the time. By 1899, he had been living for two years in the Webster House, at the corner of St. James and Cathedral streets. A fire broke out in the building on October 31, killing three of the guests and completely destroying the establishment. James was severely injured when he jumped from a third floor window, and died a few days later. ${ }^{117}$ Although James Kidd Oswald's life encompassed a variety of adventures, there is no indication that he ever visited India. One must, therefore, look elsewhere to find the source of the manuscript letters sold to McGill University. The most likely person is James' second son, William Whitehead Oswald.

\section{William Whitehead Oswald (1873-1957)}

William Whitehead Oswald was educated at King's College, Windsor, Nova Scotia, and at McGill University ${ }^{118}$ After completing his education, in 1890 he joined the Bank 
of Montreal. His obituary recounts how the General Manager of the bank, Sir Edward Clouston, shared William's interest in sailing and was instrumental in introducing him to a friend in Standard Oil, who in turn invited him to join its new venture in India. ${ }^{119}$ Thacker's Directory indicates that as early as 1894 he was working as an assistant to C. C. Campbell, Manager of Standard Oil in Calcutta. ${ }^{120}$ The company advertised itself as dealing in American kerosene and lubricating oils. One can hypothesize that William acquired the Gobind Ram letters early in his stay and either sent them to his father, or brought them home on a visit, thereby making it possible in 1895 for James to sell the manuscripts to McGill. No records have been found, however, to indicate how or where William might have acquired the letters.

In 1901, William Oswald returned to Montreal to marry, on May 29, Katherine Ray Mitchell (1875-1940), daughter of Alexander Mitchell (1833-1915), at St. Paul's Church. ${ }^{121}$ Katherine Mitchell had graduated from McGill University in 1896 with a B.A. ${ }^{122}$ William returned with his new wife to India, where he continued working for Standard Oil. In 1904 when automobiles were being introduced into India, he was reputed to have had the fourth car in Calcutta. In 1910, he was transferred to Constantinople to open Standard Oil's office there. ${ }^{123}$ When Walter Teagle purchased holdings in Peru for Standard Oil through the Imperial Oil Company, William was sent there around 1914 to help oversee operations. ${ }^{124}$ Two years later, he was recalled to Montreal, where Walter Teagle and Imperial Oil were based. After the First World War, in 1919, William was then sent to Paris where Standard Oil was in the process of establishing a producing office. ${ }^{125} \mathrm{He}$ subsequently served as Director of the Anglo-American Oil Co. in London from 1921 to 1929 , and retired in $1933 .{ }^{126}$ In England, the family lived at White Knight, a house on the St. George's Hill estate near Weybridge in Surrey. William was a member of the Royal Southern Yacht Club near Southhampton. His yachts included Dandy, Memphis, and finally the schooner Lelanta II which he sold three years before in death in 1957. His wife Katherine had predeceased him in 1940, at which time White Knight was commandeered for the war effort. William made yearly visits to Montreal until the start of the Second World War; and at the time of his death in 1957, his grandson Patrick Oswald was studying at McGill University.

\section{THE MANUSCRIPTS Physical properties and script}

The paper on which the letters are written appears to have been made according to a Persian recipe distinguishable by its irregular laid lines. ${ }^{127}$ The paper is sprinkled, perhaps with ink, and letters " $B$ " and " $C$ " have specks that glitter, possibly indicating the presence of silver, mica, or a similar substance in the ink. Item $A$ has diamond-shaped patches of gold leaf imbedded in its paper. The language used throughout the letters is Persian, the language of official correspondence in the Mughal Empire in India, and adopted by the East India Company during the earlier period of its administration. The script is of the ShikastaNastāliq hand, with the characteristic reversed $n \bar{u} n$, but it also contains features of Ta'liq such as the unconventional joining of letters and the use (though inconsistent) of the tarvis or head serifs. Several other features of the writing style that are common to letters written at that time can be noted. There is frequent overlining across the extent of the text at the commencement of first letter. ${ }^{128}$ As the text reaches the bottom of the page, the lines are written closer together, and the side margins are used to complete the letter. ${ }^{129}$ The letters end with the formulaic $b \bar{a} d .{ }^{130}$ Another common feature is the "stacking" of the words at the end of lines. ${ }^{131}$ There is also the typical absence of dots and diacritical vowels in the formation of the words ${ }^{132}$

One envelope is included with the collection of manuscript letters. In addition to containing the name of the addressee on the front, the 
reverse displays the seal of the sender. The date in the upper left hand corner of the seal is 1188 , presumably of the Hijri calendar which would correspond with Apr. 1774 to Feb. 1775 C.E. A second date would appear to be indicated by the numerals appearing towards the middle of the seal-two on the left hand side and two in the middle right. If Persian, the numerals appear to be $15[?] 7$, the third numeral being unfamiliar. The calendar used for this date is unclear, since it does not seem to match the dating of the more common calendars. A hand-written date appears on the front of the envelope as " $24 \mathrm{M}$ [ar]ch [17]75" which would equal Friday, 22 Muharram 1189 on the Hijri calendar. Taking the envelope to have contained one of the three letters, one letter was sent by Rājah Gōbind Rām Bahādur to David Anderson early in $1775 .^{133}$ From the content of Letter " $\mathrm{B}$ " discussed at the beginning of this article, it was written in 1773 .

Other letters written to David Anderson towards the end of the $18^{\text {th }}$ century can be found in the Anderson Collection at Anderson of Northfield in Fife, Scotland. ${ }^{134}$ The letters appear to be of similar composition, and are similarly accompanied by envelopes, one bearing the seal of the Mughal emperor, Shah Alam. Also part of the Anderson Collection are seals, one bearing the Persian inscription: "Bahadur Dilawar Jang, Mister Daud Andersin, Fakhr ud-Dawla, 1198," the date being approximately equivalent to A.D. 1783. The paintings in the collection include several portraits of David Anderson; one miniature by George Engleheart is exceptionally striking. ${ }^{135}$

\section{Translations of the letters}

The manuscript letters received by McGill University in 1895 were accompanied by handwritten translations, with the note written by James Kidd Oswald, "My Moonshee tells me that the letters are worth a lot, the paper being hand made which accounts for its good condition, the writing he had some difficulty in translating, as the letters are somewhat of an old style."

\section{Translation of Letter " $A$ "}

I owe service to your threshold.

$\mathrm{O}$ master see again with kindness to this slave.

Most merciful and kind sir,

Since the time you left this helpless one and went to your home; this poor fellow from the revolution of time fell a victim to many a disease beyond description and for three or four years was confined to bed and had not the power of motion. Whatever I got from you has all been spent in my treatment. By the grace of God I am now a little better and have escaped the danger, but I am not yet strong enough to offer my service to you. With great difficulty I reached Calcutta and went here and there without any profit. None of the old Sahibs with whom I was acquainted are here. Tafazul Hossain Khan Sahib who is now in a high position paid no attention to my complaints and by the reverse of my fortune nothing came out good. As I have great hopes to receive your help in this wretched time I hope you will extend your helping hand toward me. The small income which I had from [?] has now been stopped. I am now in a helpless position and in despair. I beg for a letter of recommendation to $\mathrm{Mr}$. Johnson Sahib. Undoubtedly some help will be given to me otherwise I do not see any way of my livelihood beyond this.

I have nothing more to say and pray to God that the sun of your life, wealth, position and dignity may shine forever. 


\section{Translation of Letter "B"}

Honoured and Respected Sir

After expressing a desire of meeting you may this be known to you that before this, your kind note was received; in reply to that I have sent you two letters, which I hope have reached you. I have come to know from your younger brother that on account of pressure of business you could not answer me. I pray to God that you may always be entrusted with government affairs. A few days ago I went with $\mathrm{Mr}$. Milton to Plassey to receive His Excellency the Governor; after obtaining audience we went to Madhubpur where halt was made for four or five days and there he held Durbars to receive visitors. He was very courteous. On the $17^{\text {th }}$ of Rabi Ussani he started for the west. Accordingly we went to Sadiqbagh to bid him farewell when he was already on board ship, and paid him our due respects and took leave of him. I have extreme desire to see you. If advisable kindly drop a few lines to $\mathrm{Mr}$. Milton for my future prospects. I beg you to keep me informed of your well being and pray to God that you may attain the highest position.

P. S. If advisable please tender my respects to Lord Sahib and to Tom Karim Sahib.

\section{Translation of Letter "C"}

Most merciful and Kind Sir

After expressing my great desire to see you which I my pen cannot describe. Since a long time your kind letter has not reached me. Consequently every now and then I expect your kind letter and hope you will drop me a few lines stating your health. And my humble desire to you is that by way of kindness state full particulars about you for which I will be highly obliged, and whatever duty you think befitting me, will be good enough to direct me, which I shall perform with great delight.

Your days of happiness and prosperity may remain long.

\section{Evaluation of the Translation}

Comparison with the original manuscript leads to the conclusion that, for the most part, the translation by the munshi gives the correct meaning. Letter "A." opens with a poem that the author has perhaps composed himself; expressing his desire for a favour. ${ }^{136}$ The writer uses the term namakkhōr. [meaning literally "one who has eaten salt"] for the one he is addressing. By implication, the addressee is seen as one who has taken care of the addresser in the past and will do so in the future again. He is presenting himself as a dependent person. The third person and plural forms are used to express honour. The writer opens with a lament, which might be translated more idiomatically as "In this town I had no one but you, but now you have left me without anyone." The phrase, "revolution of time" might be better translated as "wrong movement of the spheres" or in contemporary terms, "a bad alignment of the stars." In addition to the mention of disease, there is the implication of impoverishment and helplessness, resulting in unexplainable nervousness. "I am now a little better" carries the idea that there was barely a spark of life that has now been revived. The writer comments that after arriving in Calcutta, none of the old friends-sahibs could refer to friendswhich he had as a villager are now available in the city. Even his persistence to the point of rudeness was met with refusal by Tafazzul Husayn Khan. The small income he had from properties rented out to others and from "qāzī" [meaning unclear in this context] had stopped. In closing, the writer brings in another proverb, omitted from the munshi's translation: "The chief himself knows 
how to bring up his own servant," meaning that the addressee will know what to do to help the one asking for help; and just as the master benefits from the labour of the servant whom he takes care of, so the addressee will also benefit by whatever help he might offer the writer. Since poetic language is used throughout, a literal translation would not do justice to the letters' flowery expressions.

Briefly, Letter "B" opens with a prayer, not found in the original translation, "May you be healthy, $\mathrm{O}$ you who are the source of pride of the needy." An amended translation of the writer's salutation would be, "Your expression of kindness [i.e. letter] was received. In response to that I sent two letters of request. I am waiting for a reply." Mention is made of "your brother who has been kind to us..." The account of the meeting with Governor Hastings is basically as given in the existing translation, except that the translation fails to adequately convey the embellished language used in the original. "With the pleasure of his meeting we gained the happiness of heart" becomes "after obtaining audience" in the translation. The use of the honorific sābib wälid that precedes the names like "Milton Sahib" raises some questions; the accompanying translation has chosen to use "Mr" at that point. There appear to be several misspellings in the texts of the Letter "B," as if it were written by someone not fully acquainted with the Persian language. For example, at the start of the letter, $S$ has been substituted for $ق$ in aurāq [papers], the plural of waraqa; and earlier perhaps $Z$ has been substituted for 0 in mehrban.

The munshis translation of Letter " $\mathrm{C}$ " is satisfactory. Letters "B" and "C" appear to be written in a different hand from letter "A." The same person could, however, have dictated both, or written one and dictated the other two.

\section{ENDNOTES}

1 This brief historical review is taken from: Barbara Daly Metcalf and Thomas R. Metcalf, A Concise History of India, Cambridge Concise Histories (Cambridge, UK: Cambridge University Press, 2002), 50-55. I would like to thank Dr. Richard Virr, Head of Rare Books and Special Collections and Curator of Manuscripts, for his direction and encouragement in researching these manuscripts and their history, during my time of student employment at the McGill Library.

2 India. Imperial Record Department. Calendar of Persian Correspondence, being Letters which Passed Between Some of the Company's Servants and Indian Rulers and Notables, (Calcutta: Government of India Central Publication Branch, 1930), 7, 1785-1787: 11, n 4; Richard B. Barnett, North India between Empires: Awadh, the Mughals, and the British 1720-1801 (Berkeley, CA: University of California Press, 1980), 180 n 33.

${ }^{3}$ Calendar of Persian Correspondence, . 7, 1785-1787:.11, n 4; Purnendu Basu, Oudh and the East India Company, 1785 1801 (Lucknow: Maxwell Company, 1943), 17.

${ }^{4}$ Calendar of Persian Correspondence, 5, 1776-1780:. 247, 352. In CPC. 7: 28, the name is given as "Rao Anant Rao," where he is described as waiting on Prince Jahāndār Shah.

${ }^{5}$ Walsh, J. H. Tull, A History of Murshidabad District (Bengal) with Biographies of Some of its Noted Families (London: Jarrold \& Sons, 1902), 18-20.

${ }^{6}$ Abdul Majed Khan, The Transition in Bengal, 1756-1775: A Study of Saiyid Mubammad Reza Khan (Cambridge, UK: Cambridge University Press, 1969), 201.

${ }^{7}$ Bengal Civilians, file O/6/21, India Office Records, British Library, 42.

${ }^{8}$ David Anderson, Moidapore, near Moorshedabad, to his parents, 20 Dec. 1772, British library, folio 90v, Add. Mss. 45,438 .

${ }^{9}$ Ibid., folio $91 \mathrm{r}$.

${ }^{10}$ Jones, M. E. Monckton, Warren Hastings in Bengal, 1772 1774, Oxford Historical and Literary Studies, 9 (Oxford: Claredon Press, 1918), 339.

${ }^{11}$ Anderson to his parents, 1772.

12 Johnson's advancements proceeded as follows: 1771, Assistant in Accountants office; 1772, Assistant to the President and Governor; 1773, also Assistant to the Accountant to the Khalsa; 1774, Assistant to the Cashkeeper and Deputy Accountant to the Revenue Board; 1776, Factor holding the same offices also Judge Advocate General. Bengal Civilians, file O/6/25, India Office Records, British Library, 987.

${ }^{13}$ Toby Falk and Mildred Archer, Indian Miniatures in the India Office Library (London: Sotheby Parke Bernet, 1981), 14-17.

${ }^{14}$ Calendar of Persian Correspondence, 7, 1785-1787: 1 .

${ }^{15}$ Falk, Indian Miniatures, 24-25.

${ }^{16}$ Saiyad Athar Abbas Rizvi, A Socio-Intellectual History of the Isna 'Ashari Shi' is in India (16 to $19^{\text {th }}$ Century A.D.) (Canberra, Australia: Ma'arifat Publishing House, 1986) 2: 227.

${ }^{17}$ Ibid. 
${ }^{18}$ Muhammad Ali Khan, Nawab Saiyid. Tuffuzzool Hussain Khan, Khan-i-Alluma, Minister of Nawob Vazeer of Oudh. [An anonymous account of Tuffuzzool Hussain Khan from the Asiatic Annual Register for 1803, with other extracts and letters on the same subject. Compiled by Nawob Syed Mahomed Ali Khan.] (Secunderabad: Cheekoty Veerunnah \& Sons, 1908). Also included are extracts from Charles John Shore 'Teignworth's memoir of his father, the memoirs of John Shore, Memoir of the Life and Correspondence of John Lord Teignmouth 2 vols.(London: Hatchard, 1843).

${ }^{19}$ Gulfishan Khan, Indian Muslim Perceptions of the West during the Eighteenth Century (Karachi: Oxford University Press, 1998), 270-76. See note \#15, on p. 320 for further references.

${ }^{20}$ Juan R. I. Cole, Roots of North Indian Shi' ism in Iran and Iraq: Religion and State in Awadh, 1722-1859. Comparative Studies on Muslim Societies 6, ed. Barbara D. Metcalf (Berkeley: University of California Press, 1988), 53.

${ }^{21}$ Abu Talib Khan Isfahani, History of Asafu'd Daulah Nawab Wazir of Oudh, Being a Translation of "Tafzibu'l Ghafilin": A Contemporary Record of Events Connected with his Administrations, trans. W. Hoey (Allahabad, 1875; reprint Lucknow: Pustak Kendra, 1971). 15-17.

${ }^{22}$ Calendar of Persian Correspondence, 5, 1776-1780: 94.

${ }^{23} \mathrm{Ibid}, 99$.

${ }^{24} \mathrm{Abu}$ Talib, 28.

${ }^{25}$ Calendar of Persian Correspondence 5,1776-1780: 369.

${ }^{26}$ Ibid., 418, 420, 422-27.

${ }^{27}$ Ibid., 427-28; see also 469

${ }^{28}$ Asiatic Annual Register, 1803.

${ }^{29}$ Abu Talib, 54-55, 65.

${ }^{30}$ Basu, 23; Asiatic Annual Register, 1803, 5; Abu Talib, 69.

${ }^{31}$ Samuel Middleton was Resident at Murshidabad at that time. See: P. J. Marshall, ed. The Writings and Speeches of Edmund Burke - Volume VII: India: The Hastings Trial 1789. 1794 (Oxford: Oxford University Press, 2000) 38, note. Middleton had arrived at Calcutta in 1753, and in addition to being Resident at Murshidabad, he was also Chief Factor at Kasimbazar in 1772. He was President of Board of Trade in 1774. See: Jones, M. E. Monckton, Warren Hastings in Bengal, 1772-1774, Oxford Historical and Literary Studies 9 (Oxford: Claredon Press, 1918), 351. He had begun work at Murshidabad as Resident in January, 1765, but was replaced by Francis Sykes later that year. He was appointed chief of the newly formed Murshidabad Council of Revenue in January 1771. After the abolition of the Council, he again became Resident in 1772. See: Abdul Majed Khan, The Transition in Bengal, 1756-1775: A Study of Saiyid Muhammad Resa Khan, Cambridge South Asian Studies (Cambridge, UK: Cambridge University Press, 1969), 67, 107, 293, 327. David Anderson describes the dissolution of the Council of Revenues, the shifting of the Khalsab to Calcutta and the resulting re-arrangement of the collection of revenues in a letter dated 18 Oct. 1872 . He writes further,
"Mr. Middleton remains here as Resident with the Nabob, Collector of Rajeshahy and Chief of Cossimbazar." David Anderson to Claudius Russell, London, 18 Oct. 1772, folio 82, Add Mss 45,438, British Library. Middleton's as Resident is reflected in letters recorded in the Calendar of Persian Correspondence 4, 1772-1775: 4, 10, 22, 24, 33, $36,40,54,57,58,61,65,75,82,131,204,265,280$. He is described as delivering communications, accompanying the Nawab on official visits, paying the regular subsidy or pensions to members of the court, mediating in quarrels in the court, examining accounts, paying loans on behalf of the Company as well as handling other financial matters. He was recalled to Calcutta early in 1775 to another post, and was replaced by Mr. Martin. He is not be confused with Nathaniel Middleton, who is mentioned in the Dictionary of Indian Biography, and was appointed as Resident at Awadh, and later was called to testify at Hastings' trial.

${ }^{32}$ Warren Hastings, The Benares Diary of Warren Hastings, ed. C. Collin Davies, Camden Miscellany, 18. Camden Third Series 79 (London: Offices of the Royal Historical Society, 1948), 2-3.

${ }^{33}$ The calculations were made according to the on-line calendar converter at http://www.calendarhome.com/ converter/. The pencilled notation of " 1775 " in the translation, therefore must be disregarded. Also, the envelope with the notation " 24 Mch 75" and the seal indicating " 1188 " discussed earlier would seem to belong to a later letter.

${ }^{34}$ Calendar of Persian Correspondence 4, 1772-1775: 74. For a general overview of the trip and the personalities involved, see Jones, Warren Hastings in Bengal, 166-72.

${ }^{35}$ Antoine-Louis Henri Polier. A European Experience of the Mughal Orient The I'jaz-i Arsalani (Persian Letters, 1773-1779) of Antoine-Louis Henri Polier trans. Muzaffar Alam and Seema Alavi (Oxford: Oxford University Press, 2001), 96-97, 111. This published collection of letters by Polier also includes a helpful introduction by the translators describing the custom of letter-writing of that time.

${ }^{36}$ Ibid., 96-97.

${ }^{37}$ Abdul Majed Khan, The Transition in Bengal, 1756-1775: A Study of Saiyid Mubammad Reza Khan, (Cambridge, UK: Cambridge University Press, 1969), 224.

${ }^{38} \mathrm{Ibid} ., 256-57$.

${ }^{39}$ Ibid., 294-98.

${ }^{40}$ Selections from the Letters, Dispatches and Other State Papers Preserved in the Foreign Department of the Government of India, 1772-1785, ed. George W. Forrest, (Calcutta: Superintendent of Government Printing, India, 1890), 1: 1-2; Abdul Majed Khan, The Transition in Bengal, 17561775: A Study of Saiyid Muhammad Resa Khan, (Cambridge, UK: Cambridge University Press, 1969), 295.

${ }^{41}$ David Anderson to Claudius Russell, London, 18 Oct. 1772, British Library, folio 82v, Add. Mss. 45,438.

${ }^{42}$ Khan, The Transition in Bengal, 298-322. 
${ }^{43}$ Ibid., 330-37.

${ }^{44}$ On the role of the Resident, see: Michael H. Fisher, "The Resident in Court Ritual, 1764-1858," Modern Asian Studies 24, no. 3 (1990): 429-35.

${ }^{45}$ Ashirbadi Lal Srivastava, Shuja-ud-Daulah, (Lahore: The Minerva Book Shop, 1945), 2, 1765-1775: 205-06.

${ }^{46}$ Ibid., 219-21.

${ }^{47}$ Calendar of Persian Correspondence, 4, 1772-1775: 286, 294, 297.

${ }^{48}$ Ibid., 306, 311-12, 319, 349, 351-52.

${ }^{49}$ Calendar of Persian Correspondence, 5, 1776-1780: 27.

${ }^{50}$ Fisher, "Resident in Court Ritual," 425-26. On the British employment of vakils, see this article, 435-36.

${ }^{51}$ Calendar of Persian Correspondence, 5, 1776-1780: 100. On the granting of khil'ats, see: Stewart Gordon, Robes of Honour: Khil'at in Pre-Colonial and Colonial India (Oxford: Oxford University Press, 2003).

${ }^{52}$ Ibid., 208-09.

${ }^{53}$ Ibid., 166, 223-24, 283. The translation of a letter dated 1197 H. from Gobind Ram and Sicca Ram, two of Maharaja Scindia's vakils at Poona, to Scindia, is located among David Anderson's correspondence in the official India Office Records Home Miscellaneous series (H227/3 N. 83), at the British library. I thank David Blake of the British Library for sending me a copy of this letter.

${ }^{54}$ Calendar of Persian Correspondence, 7,1785-1787: 468.

${ }^{55}$ Ibid., 28, 46.

${ }^{56}$ Ibid., p. ix.

${ }^{57}$ Ibid., 46.

${ }^{58}$ Calendar of Persian Correspondence. 6, 1781-1785: 17, 49, $68,127,130$.

${ }^{59}$ Ibid., 72, 78, 125, 298-99, 348-50, and numerous otherssee index under "Gobind Ram, Raja."

${ }^{60}$ Ibid., 211-12.

${ }^{61}$ Ibid., 219. Johnson, who appears later in Gobind Ram's letters, is also mentioned in this letter.

${ }^{62}$ For the text of this letter, see India Office Records, Home Miscellaneous Series, mss. 186 on Reel 79, pp. 559-568.

${ }^{63}$ Memoirs of the Life of the Right Hon. Warren Hastings, First Governor-general of Bengal, ed G.R. Gleig (London, Richard Bentley, 1841), 3: 323.

${ }^{64}$ Gt. Brit. House of Lords. Sessional Papers, 1794-95, Trial of Warren Hastings: Minutes of the Evidence ed. F. William Torrington (New York: Oceana Publications, 1974), 2: 78889, 794-97. A copy of the original translation of the latter letter, identical to the one entered in the minutes, was sent to me by David Blake of the British Library.

${ }^{65}$ Calendar of Persian Correspondence, 7, 1785-1787: 459.

${ }^{66}$ Abdul Majed Khan, Transitions,. 250, 257-62.
${ }^{67}$ Calendar of Persian Correspondence, 3, 1770-1772: 108. James Lawrell arrived in Bengal 21 June 1758 and worked as a Writer and Assistant under the Engineer in 1759. By 1770, he was Senior Merchant and a member of the Council of Revenues at Murshidabad; 1771 Senior member of this council; 1772 eleventh Member of Council of the Governor of Fort William in Bengal; 1773 Tenth Member; 1774 Member of the board of Trade; 1775 Out of the service. See: Bengal Civilians, file O/6/25, India Office Records, British Library, p. 1060.

${ }^{68}$ Abdul Majed Khan, Transitions, 2. See also Forrest, Selections, 1:37-39; Calendar of Persian Correspondence, 4, 1772-1775: 53, 56, 72 .

${ }^{69}$ Hastings, Benares Diary,. 17, 20, 24, 31-33; Forrest, Selections, 1: 49-54; C. Collin Davies, Warren Hastings and Oudh (London: Oxford University Press, 1939), 25-26.

${ }^{70}$ John Graham arrived in Bengal 7 Oct. 1759 and worked initially as a Writer and Assistant under the Accountant. By 1766, he was Resident at Midnapore; 1767 Sheriff and Resident at Burdwan; 1768 Junior Merchant and Resident at Burdwan; 1770 Fourth of the Council of Revenue at Murshidabad; 1771 Senior Merchant and member of the Council of Revenue at Murshidabad; 1772 Thirteenth Member of the Council of the Governor of Fort William in Bengal; 1773 Twelfth member of the Council and President of the Board of Customs; 1774 Member of the Board of Trade. He was out of the service in 1775. See: Bengal Civilians, file O/6/25, India Office Records, British Library.

${ }^{71}$ Calendar of Persian Correspondence, 4, 1772-1775: 3-4.

${ }^{72}$ Thomas Graham arrived in India 31 May 1769 as Writer; 1770 Assistant to the Supervisor of Hooghly; 1772 Assistant to the Collector of Hooghly; 1773 Without employ; 1774 Factor and Secretary at Burdwan; 1775 Assistant at Patna Factory under the Board of Trade; 1777 Junior Merchant and Resident at Benares; 1780 Without employ; 1782 Senior Merchant and Persian Interpreter to Commander in Chief (Sir Eyre Coote). In 1788, he became a Member of the Board of Revenue, Calcutta; and in 1791 was appointed Provisional Member of the Supreme Council. See: Bengal Civilians, file O/6/24, India Office Records, British Library, p. 759.

${ }^{73}$ Personal Records, file O/6/3, India Office Records, British Library, p. 271. His correspondence and papers, 1774-1818, are held at Scottish Record Office (nos. 213651); see: Riddick, 202-03. A detailed list of the contents can be found in M. D. Wainwright and Noel Matthews, $A$ Guide to Western Manuscripts and Documents in the British Isles Relating to South and South East Asia (London: Oxford University Press, 1965), 394-95.

${ }^{74}$ Suprakash Sanyal, Benares and the English East India Company, 1764-1795 (Calcutta: World Press, 1979), 83-97. David Anderson is termed Graham's “business partner," 84. See also Descriptive List of Secret Department Records, ed. K. D. Bhargava, (Delhi: National Archives of India, 1960), 2, 1776-1780: 132, 139, 144 . 
${ }^{75}$ Mustepha, Murshidabad, to David Anderson 26 May 1773, folio 279, Add. Mss. 45,430, British Library.

${ }^{76}$ Selections from the Letters, Despatches and Other State Papers Preserved in the Foreign Department of the Government of India, 1772-1785, ed. George W. Forrest (Calcutta: Superintendent of Government Printing, India, 1890), 3: 822-23.

${ }^{77}$ Asiatic Annual Register, 1803, "Characters: An Account of the Life of Tofuzzel Hssein Khan, the Vakeel, or Ambassador, of the Nabob Vizier Assof-ud-Dowlah, at Calcutta, during the Government of Marquis Cornwallis", 2.

${ }^{78}$ C. E. Buckland, Dictionary of Indian Biography (Varanasi: Indological Book House, 1971), 13.

79 "Anderson of Northfield formerly of St. Germains and Bourhouse," Burke's Genealogical and Heraldic History of the Landed Gentry $18^{\text {th }}$ ed., (London: Burke's Peerage Ltd., 1972), 3:22-23. This source traces the descendants of David Anderson to the present generation.

${ }^{80}$ http://www.lib.ed.ac.uk/lib/about/bgallery/Gallery/ records/eighteen/anderson.html

${ }^{81}$ http://www.andersonofnorthfield.net/. Other papers of David Anderson are located at the British Library, both in the Manuscript Collections and the Oriental and India Office Collections.

${ }^{82}$ Charles Hamilton, The Hedáya, or Guide; A Commentary on the Mussulman Laws: Translated by Order of the GovernorGeneral and Council of Bengal, 4 vols. (London: T. Bensley, 1791), xlv.

${ }^{83}$ McGill University Archives. RG 40, Cont. 56, Letter Book no.1, Dec. 13, 1893-Apr. 20, 1896, p. 514. I did not find a follow-up letter from Gould in the succeeding four months of records.

${ }^{84}$ McGill University Archives. RG 40, Cont. 2, 1893-1898L, File 1895 - "O." There does not appear to be any further letter from Oswald in the next two years.

${ }^{85}$ Lovell's Montreal Directory for 1895-96, 868.

${ }^{86}$ George Maclean Rose, A Cyclopaedia of Canadian Biography, Being Chiefly Men of the Time: A Collection of persons distinguished in professional and political life, leaders in the commerce and industry of Canada, and successful pioneers (Toronto: Rose Pub. Co., 1886).

${ }^{87}$ Lovell's Montreal Directory for 1870-71 lists the Oswald brothers as living at 273 Bleury in Montreal, and also carries an advertisement for the insurance company which they managed. Mitchell's daughter Katherine Ray married J. K. Oswald's son William some 30 years later.

${ }^{88}$ W. R. Oswald, The Canadian Militia: an historical sketch, a lecture delivered to the Young Men's Association of St. Paul's Church, Montreal, on $8^{\text {th }}$ March, 1886 (n.p. 1886). See also Francis Wayland Campbell, The Fenian invasions of Canada of 1866 and 1870 and the operations of the Montreal Militia Brigade in connection therewith: a lecture delivered before the Montreal Military Institute, April 23 ${ }^{\text {rd }}, 1898$ (Montreal: John Lovell \& Son, 1904), 34; and The Fenian raid of 1870 by Reporters present at the scenes (Montreal: "Witness" Printing House, 1870), 67.

${ }^{89}$ John P. Roche, “Canadian Golf," Outing (June 1898), 26162.

${ }^{90}$ Serge Goudreau, "Émergence d'un marché boursier montréalais (1840-1874)," Ministère des Finances du Québec - 2004.04.01, Publication no. 19, pp. 44-48; found online at http://www.callisto.si.usherb.ca:8080/ grhif/Bibliotheque/Pdf/pub19r1.pdf.

${ }^{91}$ The Glenbow Archives in Calgary include letters from J. $\mathrm{K}$. Oswald written from Montreal, after he returned there in the 1890s. These letters are found in the Wesley F. Orr papers, M 928, v. 2, pp. 58, 88, 104, 160; v. 3, pp. 190, 201.

92 “Capt. Oswald Dead," The Gazette, 9 Nov. 1899.

${ }^{93}$ The Winnipeg Times, "Provincial Appointments," 7 November, 1882, p. 6.

${ }^{94}$ Lawrence H. Bussard, "Early History of Calgary," M. A. Thesis, University of Alberta, 1935, leaves 52-58. See advertisements in the Edmonton Bulletin, July 1883 to Dec. 1883 , and in MacLeod Gazette, 14 July 1883. The Glenbow Archives of the Glenbow Museum in Calgary have a picture, NA-659-17, which includes Capt. J. K. Oswald, dated August 1883.

${ }^{95}$ W. B. Scarth, to John A. Macdonald, 21 Jan. 1883, Prime Minister's Fonds, Sir John A. Macdonald, MG26 A, Vol. 261, Reel C1677, pp. 118869 to 118871 , Library and Archives Canada.

${ }^{96}$ W. B. Scarth, Toronto, to John A. Macdonald, 5 Feb. 1883 , Prime Minister's Fonds, Sir John A. Macdonald, MG26 A, Vol. 5, Reel C1489, pp. 1558 to 1560, Library and Archives Canada.

${ }_{97}$ W. B. Scarth, Calgary, to John A. Macdonald, 2 Jul. 1883, Prime Minister's Fonds, Sir John A. Macdonald, MG26 A, Vol. 5, Reel C1489, pp. 1561 to 1563, Library and Archives Canada.

98 The North-West Territories Gazette, Regina, 19 January 1884, pp. 3-5.

${ }^{99}$ The North-West Territories Gazette, Regina, 27 May, 1884, pp. 2-3.

${ }^{100}$ A Lady Stephen, Montreal, to John A. Macdonald, 23 Feb. 1885, Prime Minister's Fonds, Sir John A. Macdonald, MG26 A, Vol. 412, Reel C1770, pp. 199454 to 199457, Library and Archives Canada.

101 "Nomination of Candidates for the North West Council," Calgary Herald, 18 June 1884, p. 4.

${ }^{102}$ See archival record at: http://www.saskarchives.com/ web/seld/1-00.pdf.

103 "Grand Victory", The Nor'-Wester 1 July 1884, p. 1.

${ }^{104}$ Journals of the Council of the North-West Territories of Canada, Sixth Legislative Session Begun and Holden at Regina, on the $3^{\text {rd }}$ Day of July, and closed on the $6^{\text {th }}$ Day of August, 1884. His Honor Edgar Dewdney, Lieutenant-Governor, 
Session of 1884 (Regina: Amédée E. Forget, 1886), pp. 11, $16,24,54$.

105 "Mass Meeting at Calgary," The MacLeod Gazette, 12 December 1884, p. 2. Interestingly, the motion was seconded by his former rival, J. D. Geddes.

106 "Alberta at Ottawa," The MacLeod Gazette, 14 March 1885, p. 2.

${ }^{107}$ The march and skirmishes that took place along the way, including the Battle of Frenchman Butte, are described in a book by Wayne Brown, Steele's Scouts: Samuel Benfield Steele and the North-West Rebellion (Surrey, BC: Heritage House Publishing, 2001). Some mention is made of the work of Capt. J. K. Oswald in leading his scouts, but not in any detail. See Glenbow Archives, photograph no. NA-936-22 for a picture of Steele's Scouts. See also, "Oswald's Scouts," Calgary Herald (16 Apr. 1885), p. 4.

108 "The Alberta Scouts: A Detailed Account of their Campaign," Calgary Herald (22 July 1885), p. 3.

${ }^{109}$ From there he wrote the Ministry of the Interior, requesting maps of the North West Territories, the region to which he expected the infantry would shortly be sent. He mentions that he had been in Ottawa (thus presumably Montreal as well) in the previous November. Government of Canada Files, RG 15, Interior, Series D-II-1 Volume 415, Reel T-13117, file 107810, Canadian National Archives.

${ }^{110}$ W. R. Oswald, The Canadian Militia, p. 12-14.

${ }^{111}$ The Church records of St. Paul's Presbyterian, Montreal, QC, (mflm. 1182D, Montreal City Library) carry the marriage license for James Kidd Oswald and Alice Ann Whitehead, for 5 October 1870.

${ }^{112}$ National Archives of Canada. Census, 1881. St. Antoine ward, no. 5, Subdivision, page 42, (microfilm, C-13219).

${ }^{113}$ The church register for St. James the Apostle, Anglican, 1882, folios 51, 49, and 54 .

${ }^{114}$ On E. A. Whitehead, see "Colonel Edward Ashworth Whitehead," in William Henry Atherton, Montreal from 1535 to 1914, (Montreal: S. J.Clarke, 1914), 3: 442-44.

${ }^{115}$ Graham's maternal grandfather, Rev. Edward Black was the founder of St. Paul's Presbyterian Church in Montreal. Her brother was Edward Black Greenshields who had fought with J. K. Oswald at Eccles Hill in 1870. See also Gordon Burr, "Edward Black Greenshields: The McGill Connection," Fontanus 11 (2003): 129-143.

116"Lt.-Col. W. R. Oswald," The Gazette, 5 June, 1899, p. 8.

117 "Holocaust at the Webster House," The Montreal Daily Star, 31 Oct. 1899, pp. 10-11; 9 Nov. 1899.

${ }^{118}$ Burke's Landed Gentry, $18^{\text {th }}$ ed., 549.

${ }^{119}$ Donald Newnham, "City Man's Odyssey: Canadian Played Role in Oil Group," The Montreal Star (27 Feb. 1957), p. 12.

${ }^{120}$ Thacker's Indian Directory 1894 embracing the whole of British India \& Native States with complete and detailed information of the cities of Calcutta, Madras, Bombay,
Allababad, Lahore, Simla, Rangoon, Ec. (Calcutta: Thacker, Spink and Co., 1894), 306.

${ }^{121}$ Church registers for St. Paul's Presbyterian, 1901, f.20. William and Katherine had two sons, William Alexander Hugh (1905-1974) and Marshall St. John (1911-?). In 1933, William Alexander Hugh married Rose-Marie Leahy, whose lineage can also be traced back to Mordaunt Ricketts who served India. The couple had two sons, William Richard Michael (Sir Michael) (1934- ), and Arthur James Patrick (1937- ). I want to thank Sir Michael and Lady Angela of Norfolk, England, for their kind hospitality and assistance in providing information about their family. I also wish to thank Commodore A. J. Patrick Oswald of Vancouver for providing several obituaries of his father and other family history.

${ }^{122}$ McGill University of Montreal Directory of Graduates, 1924 ed., p. 286. Her address in 1924 was listed as White Knight, 84 George's Hill, Waybridge, Surrey, England.

${ }^{123}$ On the efforts of Standard Oil to establish their company in the Middle East, see: George Sweek Gibb and Evelyn H. Knowlton, The Resurgent Years, 1911-1927, vol. 2 of the History of Standard Oil Company (New Jersey), (New York: Harper \& Brothers, 1956) pp. 284-285.

${ }^{124}$ On Standard Oil's work in Peru, see ibid. pp. 94-102.

${ }^{125}$ Ibid. p. 176.

${ }^{126}$ Burke's Landed Gentry, $18^{\text {th }}$ ed., 549.

${ }^{127}$ I am grateful to Adam Gacek, Librarian of the Islamic Studies Library, McGill University, for his assistance in analyzing the physical characteristics of the manuscripts.

${ }^{128}$ See William L. Hanaway and Brian Spooner, Reading Nasta'liq: Persian and Urdu Hands from 1500 to the Present. Bibliotheca Iranica. Literature Series, 3 (Costa Mesa, CA: Mazda Publishers, 1995), p. 9. This overlining is absent from letters $B$ and $C$, perhaps because they were less formal; see ibid., p. 49.

${ }^{129}$ Ibid., pp. 10 (6) and 10 (7).

${ }^{130}$ Ibid., p. 10 (8); see examples 7 and 36.

${ }^{131}$ Ibid., p. 11 (14).

${ }^{132}$ Ibid., p. 12 (18).

${ }^{133}$ With regard to the use of seals, a letter from the Governor-General to Nawab Muhammad Riza Khan on Apr. 30, 1776 notes that two seals engraved at Fyzabad, one bearing the name of Raja Gobind Ram and the other that of Thomas Andrews, were being brought to Calcutta by the peons of Raja Gobind Ram. The peons had been seized by the chaukidars at Kulna and the seals taken from them. The letter is to request that the matter be looked into and that that seals be restored to the Raja's men. See: India. Imperial Record Department. Calendar of Persian Correspondence, being Letters which Passed Between Some of the Company's Servants and Indian Rulers and Notables, vol. 5, 177680 (Calcutta: Government of India Central Publication Branch, 1930), 14-15. 
${ }^{134}$ I would like to thank Stephen Aynscough, great, great, great, great grandson of David Anderson, for his generosity in providing information about his family and sending me scans of the letters, envelopes, seals, and portraits.

${ }^{135}$ The Anderson Collection is on display under the Doors Open Day (East Fife) Scheme and at other times by request. See http://www.andersonofnorthfield.net.

${ }^{136}$ The existing translations were compared to the originals by Mohammad Ghassemi, at McGill University June 14, 2002. 